\title{
Complexities of Governmental Affordable Housing Programmes for Urban Poor in Slums of India
}

\author{
Sukanya Ghosh ${ }^{1}$, (Dr.) Souvanic Roy ${ }^{2}$ \\ ${ }^{1}$ Doctoral Fellow, Department of Architecture, Town and Regional Planning, Indian Institute of Engineering Science \& Technology, \\ Shibpur, India
}

${ }^{2}$ Professor, Department of Architecture, Town and Regional Planning, Indian Institute of Engineering Science \& Technology, Shibpur, India

\begin{abstract}
In order to increase housing stock, since independence, affordable housing programmes of Government of India have evolved and refined over years based on various policies. Currently urban housing programmes have been framed on the National Urban Housing and Habitat Policy (NUHHP), 2007 which emphasized that affordable housing is to be made available to the target group i.e. urban poor households as they lack affordability. Strategy framework of the Indian Federal Government to facilitate providing housing is multiple partnerships of States with various stakeholders. Though studies apparently indicate quantitative parameters like income as the main factor for affordability in governmental programmes, there are other affordability issues also which are neither straightforward nor quantitative but subjective and require detailed scrutiny. Moreover, problems of affordable housing in India are far more complex due to diverse ground realities. So, problems are to be looked into in an integrated manner.Article emphasises that unless these qualitative and intangible issues are understood, difficulties would persist for successful implementation of housing programmes.
\end{abstract}

Keywords: Affordable Housing, Housing Affordability, Urban Poor, Housing Policy, Governmental Programmes

\section{Introduction}

\subsection{Understanding the Meaning of "Affordable Housing"}

Internationally there are many definitions available those define affordable housing. Definitions vary from country to country based on emphasis of different parameters. Parameters are from various points of view, like social, economic, physical etc. or even combinations of these aspects.

According to the report on Affordable Land and Housing in Asia, United Nations Human Settlements Programme [1], affordable housing is broadly defined as that which is adequate in quality and location and does not cost so much that it prohibits its occupants meeting other basic living costs or threatens their enjoyment of basic human rights. Thus UN-HABITAT has given more stress on quality \& location and also clarified that occupants of an ,affordable house $^{\text {ee }}$ would be in a position to meet other basic living costs.

Internationally, a basic housing unit that provides a minimum amount of personal space and basic amenities is accessible at 20 to 40 per cent of gross monthly household income for either rent or mortgage. However, the requirement of minimum personal space as well as basic amenities differs across countries, and even among developing countries [2]. In Australia, the National Affordable Housing Summit Group developed their definition of affordable housing as housing which is "reasonably adequate in standard and location for lower or middle income households and does not cost so much that a household is unlikely to be able to meet other basic needs on a sustainable basis" [3]. In the United Kingdom affordable housing includes "social rented and intermediate housing, provided to specified eligible households whose needs are not met by the market" [4].

Affordable housing can be thought of as "physically adequate housing that is made available to those who, without some special intervention by government or special arrangement by the providers of housing, could not afford the rent or mortgage payments for such housing [5]".Affordable housing could be on ownership basis or as rental and thus the term is tenure neutral. In recent years, the term ,affordable housing ${ }^{\text {ee }}$ has been used as an alternative to terms such as ,publice, ,social ${ }^{\text {ee }}$ or ,low coste housing [6].

\subsection{Understanding "Housing Affordability"}

Affordability is one of the core elements of „The Right to Adequate Housing ${ }^{\text {ee }}$ as defined by General Comment No. 4 of the United Nations Committee on Economic, Social and Cultural Rights. The right to adequate housing include the following: (a) Legal security of tenure; (b) Availability of services, materials, facilities and infrastructure; (c) Affordability; (d) Habitability; (e) Accessibility; (f ) Location; and (g) Cultural adequacy.Affordability is a key component of Adequate Housing [ ${ }^{1}$ The Right to Adequate Housing: Adequate housing must provide more than four walls and a roof. A number of conditions must be met before particular forms of shelter can be considered to constitute "adequate housing." These elements are just as fundamental as the basic supply and availability of housing - UNHABITAT (2011)]. It is especially important in terms the success of policies, programmes, and projects in reaching and benefiting their intended beneficiaries, almost always low-income households as indicated in UN-HABITAT Report 2011.

There are diverse and incompatible definitions of housing affordability [7]. "Housing affordability"e refers to the capacity of households to meet housing costs while 


\section{International Journal of Science and Research (IJSR) \\ ISSN (Online): 2319-7064 \\ Index Copernicus Value (2013): 6.14 | Impact Factor (2014): 5.611}

maintaining the ability to meet other basic costs of living" [8]. „Affordabilitye denotes an individual's capacity to exercise choice in the marketplace. However, the term usually denoting the maximum amount of income which households should be expected to pay for their housing. In another definition, "Affordability is concerned with securing some given standard of housing (or different standards) at a price or rent which does not impose, in the eye of some third party (usually government) an unreasonable burden on household incomes" [9].

As classified by DTZ New Zealand [10], housing affordability has three key dimensions -

1. Affordability for renters;

2. Affordability for would be home owners; and

3. Affordability for existing homeowners.

Housing affordability is a tenure-neutral term that denotes the relationship between household income and household expenditure on housing costs [11].

In general, "Affordability" as a concept is very generic and could have different meanings for different people based on differences in income levels. Different countries have defined affordable housing to present the economic potential of an individual buying a house. In developed countries like the US and Canada, a commonly accepted guideline for affordable housing is that the cost of housing should not exceed 30 per cent of the gross income of the household.

Assessment of housing affordability is the primary step for formulating any affordable housing programme. There are several factors identified through literature study that contribute to the affordability of housing like household income, house price, composition of household, spending and saving habits and policies of funding agencies etc. While there is no universally agreed measure of what constitutes ,affordable housinge, there are three common measures, which are associated with two components: housing costs and household income. There are measures like:

1) House price-to-income ratio

2) House rent-to income ratio

3) Residual income (minimum income required to meet non-housing needs at basic level) assessment

\section{Assessing Housing Affordability of Poor is a Complex Problem}

Housing has various issues like location, tenure, size etc. At the same time, requirements and preferences for housing vary and are not same for different type of households. Location is an important component of housing for the poor. However, locational preferences of different categories of the poor vary. Compromise is made on location of housing, especially in case of slum relocation programmes. Similarly, compromise is also made by providing small sized units to fit within the criteria of affordability limits. Depending on family need, people may prefer to live in slum in ,substandard dwelling units ${ }^{\text {ee }}$ in order to save money for other priorities like food, health, commuting expenses to place of occupation, children's education and marriage or other issues. People may prefer to live in housing that fail to meet physical standard, in overcrowded conditions, with insecure tenure, or in unsafe or inaccessible locations. Housing Affordability is relative and varies from person to person and has three key dimensions like affordability for renters, would be home owners and existing homeowners. It is the choice of people to afford a house considering other aspects.

Housing Affordability Index only measures median household income in relation to the income needed to purchase/rent a median-priced house. But the Index does not consider other factors. One of the important factors is transportation cost as the issue of affordability, especially for poor is closely linked with location of housing. Again, disposable income for every household which is one of the key factors to assess affordability is subjective. On the other hand, assessing how the affordability issues of a household change over a period of time throughout the life-cycle is also not possible.

Moreover, urban poor are not a homogeneous group and to categorise them only in terms of income level of the households, leaving other diverse factors, may lead to wrong conclusion about their housing preferences. Other important elements which need to be taken into account are length of stay in the city, stability of job, type of job, composition of family, consumption/expenditure patternetc [12]. Affordability can be experienced by different household types in varied ways. Singles, sole parents and couples with young children and couples with grown up children will have different affordability even if they are in the same income bracket. Accordingly, they will adapt their situations to afford expenditure on housing. More complexity is added to the issue of affordability since diverse factors are related to it like transport, employment, health, education etc. No measure or indicator of affordability can assess in quantifiable terms how households as well as individuals adapt their lives to mitigate affordability problems and how households shift priorities over the period. Even highly subsidised housing may not attract the target groups to opt for the house. The willingness to pay for the house may be very low or nil and highly subsidised house will still be unaffordable. People search for a superior package of housing than what they have at present as per their perception.

In the research findings as summarised below, Yates, Judith et al (2007) endorsed that assessing Housing affordability is a problem. It gave emphasis on the complexity and diversity of the problem and affordability varies household to household:-

- Housing affordability is a large and widespread problem.

- Housing affordability is a structural problem.

- Causes of affordability problems are complex and diverse. Major driving factors can be found both within the housing system and beyond it.

- Affordability problems have specific spatial and cyclical dimensions.

- Individual households experience and address housing affordability problems in different ways

Almost all affordability analysis is static in that it captures the situation at the time of data collection. Because every

\section{Volume 5 Issue 1, January 2016}




\section{International Journal of Science and Research (IJSR) \\ ISSN (Online): 2319-7064}

Index Copernicus Value (2013): 6.14 | Impact Factor (2014): 5.611

survey covers a different set of households, the capacity to understand how affordability affects individual households over their lifecycle is constrained. To state the problem of housing depends on who needs the statement and what it is used [13].

Turner, John F C in his book ,Housing by people mentioned that forecasts of housing demands always fail. This occurs mainly because it is wrongly supposed that people will spend a given proportion of income on housing. These calculations of what people will spend are based upon what bank or government agency officials assume people can invest......The variety in what people will spend is enormous, even within the same income bracket....... For instance, the majority of people with median incomes, especially when they are young, are prepared to consider living in a slum in order to save for marriages, for children, for a home of their own, for school or university expenses....... The same family may jump from one priority to another at any time.....the concept of potential demand must refer to what people would invest if they had opportunities that matched their priorities. To be meaningful and useful as tools for action, people's housing needs must always be stated in terms of 'priorities'.

Turner, John F C also pointed out that all national and international housing and planning agencies misstate housing problem by applying quantitative measures to nonquantifiable or only partly quantifiable realities. It is illogical to state housing problems in the modern convention of ,deficite of units to some material standard. Housing affordability is subjective. Housing stress can be measured in terms of people's subjective experience of managing their housing costsas statedby Yates, Judith et al (2007).

Housing shortage is generally misinterpreted as housing problem. But quantifiable measures like, substandard unitse and ,units needed cee cannot be applicable to clearly define the problem of housing. Rather housing problems can be stated in terms of human needs. The problem of housing is better statedby mentioning, who need it ${ }^{\mathrm{ec}}$. As mentioned by Turner, John F C, Housing problem cannot be properly stated unless the underlying issues are understood.Affordable housing problems are neither straightforward nor well defined that can be clearly understood and as mentioned by Tamvakera $\mathrm{E}$ [14], Affordable housing is a very complex and multidimensional terminology and ,Affordable ${ }^{e e}$ housing only can have meaning (and utility) if following 3 essential questions are answered. The notion "affordable housing" is presented as "triangulation".

1) The addressed group (affordable to whom?)

2) The duration of living in affordable housing (for how long?)

3) The affordable housing standards (on what standard of affordability?)

\section{Governmental Programmes for Urban Poor in India}

\subsection{Measures Considered for Affordability}

\subsubsection{Background}

India has parliamentary system of government and federal structure that comprises of the central, states and local governments. Different local government arrangements operate in urban and rural areas. The programmes of housing in India have come a long way since 1950s. After independence, in order to substantially increase affordable housing stock, Government of India has adopted a dual policy for providing ,Housing for allee The fiscal incentives and housing sector reforms mainly target the middle and upper income groups who will be provided housing through the market process. Affordable housing programmes had been devised for the poor. Housing policy functions have been carried out by Ministry of Housing and Urban Poverty Alleviation (MoHUPA). The Ministry has been implementing various programmes based on the National Housing and Habitat Policy 2007 [15]. The policy of the Ministry has been to restrict the target group under affordable housing programmes for urban poor i.e. Economically Weaker Section (EWS) and Lower Income Group (LIG) $\left[{ }^{1}\right.$ Revision of Income Ceilings for Economically Weaker Sections (EWS) and Low Income Group (LIG) vide Circular of National Housing Bank no. NHB (ND)/MRCPD/HPC-74/21092/2012-13 dt. 29/11/2012 on the basis of advice of Ministry of Housing and Urban Poverty Alleviation (MoHUPA), Govt. of India, EWS having an annual household income up to INR 1 lakh] as per the income parameters, since it is always considered that affordability is directly linked to income only.

\subsubsection{Measures Considered}

As the Affordable Housing Programmes of Government are associated with the word affordability, parameters like ,cost of the house e, ,size of the house ${ }^{e e}$ and ,equated monthly instalment (EMI)e etc. have been decided based on income category of people. The policy of Ministry is based on a basic assumption that a household can afford a house whose cost is specific fraction to its annual income and accordingly cost ceilings for housing units in any Governmental Programmes are decided. As prescribed by the Affordable Housing Task Force, Government of India in the year 2008, various parameters for affordable housing programme for EWS and LIG groupswere finalised, like carpet area within a range of 28 to 56square metres, cost of house not exceeding 4 times gross annual household income and EMI/rent not exceeding 30 per cent of gross monthly income. Ministry considers the absolute, cross-India benchmarks based on the quantifiable aspects as mentioned above to determine the affordability for these two income category groups.

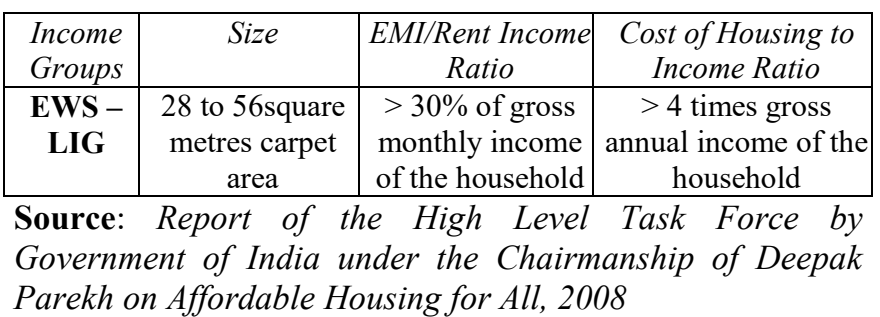

Volume 5 Issue 1, January 2016 www.ijsr.net 


\section{International Journal of Science and Research (IJSR) \\ ISSN (Online): 2319-7064 \\ Index Copernicus Value (2013): 6.14 | Impact Factor (2014): 5.611}

\subsubsection{Assessing Affordability is a Far More Complex Problem}

Urban contexts across India are diverse. As per Census of India 2011, population in urban areas vary from lowest population size of 5000 to million plus metro cities and ten million plus mega cities.Number of Urban Agglomeration/ Towns in India is 7935 as per 2011 Census. Number of urban dwellers in India accounts for about $10 \%$ of the urban population of the world and about $21 \%$ of that of Asia. Differences in urban areas exist in terms of cultural, social and economic conditions due to diversity existing within the Country. There are inequalities in income levels, occupational pattern and cost of living. Level of access to housing varies a lot with type and pattern of housing.

According to the Report of the Technical Group (TG-12), constituted by the Ministry of Housing \& Urban Poverty Alleviation, on Estimation of Urban Housing Shortage, the total urban housing shortage in the country in 2012 was recorded as 18.78 million in the beginning of the 12th Plan (2013-17). It is worth noting that 96 per cent of this shortage pertains to the economically weaker sections and the lower income groups of the society [16]. As an outcome, a considerable percentage of urban poor in India live in slums despite non-availability of basic services. As per Press Note released by Planning Commission, March,2012 on Poverty Estimates, 2009-10 the number of urban poor is 76 million. A large part of increase in urban population occurred in slums due to inability of migrants to find space in cities other than slums. As per Census 2011, the slum households in the country are 13.7 million.

Slum settlements In India differ substantially from each other not only in terms of environmental deficiencies and shelter conditions but also on income and affordability issues of slum dwellers. Slum typologies also vary. According to National Resource Centre, New Delhi, India, slums / informal housing can also be classified according to the diverse processes of land /housing supply and varying degree of tenure security in the following manner [17].

a) Slum on freehold land (inner city blighted areas),

b) Urban villages and land owned by village panchayats

c) Chawls/Bustees

d) Encroachments on public/private land (squatters)

e) Resettlement colonies on government/private leasehold land

f) Slums on the urban periphery

g) Illegal land-subdivisions/unauthorized colonies/revenue layouts/gramthana layouts (where land ownership may be legal or quasi legal but land subdivision is illegal)

h) Refugee Resettlement Colonies

i) Pavement dwellers (although small in percentage, are found in large mega-cities)

However, all slum household do not belong to the category of urban poor. Chandrasekhar and Montogomeryes [18] analysis of NSSO survey data confirms that slum dwellers and the urban poor are not synonymous, but slums are symptomatic of inflated real estate places and the policy failure.McKinsey Global Institute forecasts that the number of households that cannot afford a house could rise by an additional 13 million to reach a total of 38 million by
2030.Policy makers in India therefore face a dual challenge. First, there is a need to upgrade housing of existing slum dwellers and households living in congested and dilapidated conditions. Second, mechanisms have to be devised to ensure that the rising population in cities will have access to affordable houses [19].

India, while formulating affordable housing programmes, annual income is considered for deciding cost ceilings for housing units by using house-price to income ratio. Generally Income Survey and Household Expenditure Survey are conducted to assess affordability. Data is obtained on income/disposable income of households for formulation of projects. However, Expenditure Survey and housing costs provide only limited spatial information. Further, disposable income for every household which is considered as one of the key factors to assess affordability is subjective. Households in India not only depend upon internal income to their households but also depend upon support from the extended family and close acquaintances in the neighbourhood. There are other sources of support, both cash and non-cash, by which households meet their needs [20].

Mainly affordable housing programmes for urban poor are managed by public agencies with fiscal incentives devised centrally by the Ministry. The public agencies are governed by highly centralised policy of larger scale. Urban poor have to either adopt the centralised programmes or to stay out. They have little or no choice. It is difficult for a generalized programme to cater to the needs of all urban poor. Urban poor have fewer choices and suffer more directly from mismatches of the housing supply and their priorities [21]. Further, as multi-players/stakeholders are involved in the programmes, they all have various issues associated with own objectives and interests to participate in the programmes

\section{Conclusion}

Since governmental affordable housing programmes for urban poor in India are associated with urban poor and other players who are playing roles with multiple objectives and interests, there is need for clearer understanding of underlying/subjective/qualitative issues of the programmes by analysing the base level inherent complexities associated with affordability. Problems associated with the programmes have to be looked into in an integrated manner as the complexities of the problem are not only dealing with quantitative data but qualitative data also. Quantitative approaches have inadequacies to understand problems of the programmes as there is varied nature of housing requirements of urban poor linked with varied priorities all over the vast country. There is a need for better understanding of underlying issues to address the root causes of the problem of affordable housing programmes. Unless these problem issues are properly addressed, affordable housing under governmental programmes in India would be far from the reach of the urban poor. 


\section{International Journal of Science and Research (IJSR) \\ ISSN (Online): 2319-7064}

Index Copernicus Value (2013): 6.14 | Impact Factor (2014): 5.611

\section{References}

[1] UN-HABITAT (2011), Affordable Land and Housing in Asia, United Nations Human Settlements Programme, UN-HABITAT: Nairobi

[2] MGI (2010), India's Urban Awakening: Building Inclusive Cities, Sustaining Economic Growth, McKinsey Global Institute, McKinsey \& Company: India

[3] Disney, J. (2007), Affordable Housing in Australia Some Key Problems and Priorities for Action, Australian Housing and Urban Research Institute, Melbourne [Online].Available: http://www.ahuri.edu.au/downloads/2007_Events/AHU RI_Conf/Julian_Disney.pdf

[4] GŌV.UK (2014, June), Affordable Housing Supply. Available:

http://www.communities.gov.uk/housing/housingresear ch/housingstatistics/ definitiongeneral/

[5] Field, CG (1997), Building Consensus for Affordable Housing, Housing Policy Debate 8 (4). Available: http://www.fanniemaefoundation.org/programs/hpd/pdf/ hpd 0804 field.pdf

[6] Gabriel, M. et al. (2005), Conceptualising and Measuring the Housing Affordability Problem, National Research Venture 3: Housing Affordability for Lower Income Australians, Research Paper 1, Melbourne: AHURI: RMIT-NATSEM Research Centre

[7] Michael Stone et al.(2011), The Residual Income Approach to Housing Affordability: the Theory and the Practice, Positioning Paper no. 139, Melbourne: AHURI: Swinburne-Monash Research Centre

[8] Burke, Terry (2004), Measuring Housing Affordability, Australian Housing and Urban Canberra, Australian Government Publication Services, Issues Paper 2

[9] Maclennan, D and R Williams (1990), Affordable Housing in Britain and America. (York:JosephRowntree Foundation)

[10] DTZ (2004), Housing Costs and Affordability in New Zealand, Wellington, Centre for Housing Research, Aotearoa, New Zealand

[11] Yates, Judith et al. (2007), Housing affordability: a 21st Century Problem, National Research Venture 3: Housing Affordability for Lower Income Australians, Melbourne: AHURI: RMIT-NATSEM Research Centre.

[12] Wadhwa K. Dr. (2009), Affordable Housing for Urban Poor, National Resource Centre, School of Planning and Architecture, New Delhi, India

[13] Turner, John F C (1976), Housing by People, Marion Boyars Publishers Ltd., London.

[14] Tamvakera E. (2013), When the State has no More Money Looking for Qualitative Affordable Housing Models, MAS Thesis, Schwamendingenstrasse 62, 8050, Zürich

[15] MoHUPA (2007), National Urban Housing and Habitat Policy 2007, Ministry of Housing \& Urban Poverty Alleviation, Government of India, New Delhi

[16] MoHUPA and NBO (2013a), State of Housing in India, A Statistical Compendium, Ministry of Housing \& Urban Poverty Alleviation, Government of India, National Buildings Organisation
[17] NRC India (2010), Research Study on Slum Typology and Grading for Improvement, School of Planning and Architecture, New Delhi, India. Available: http://spa.ac.in/NRC/RSSlumTypology.pdf

[18]Chandrasekhar Mark and R. Montgomery(2010), Broadening Poverty Definitions in India: Basic Needs in Urban Housing, Working Paper Series, Poverty Reduction in Urban Areas-27, Human Settlements Programme International Institute for Environment and Development (IIED), London, UK

[19]MGI (2010), India's Urban Awakening: Building Inclusive Cities, Sustaining Economic Growth, McKinsey Global Institute, McKinsey \& Company: India

[20]Hulchanski, DJ (1995), The Concept of Housing Affordability: Six Contemporary Uses of the Housing Expenditure to Income Ratio, Housing Studies 10(4)

[21] Kundu, A. (2013), Making India Cities Slum-Free: Vision and Operationalization, Economic \& Political Weekly, April 2013, Vol. XLVIII No 17 